having taken place in England or elsewhere. I am the only explorer, after M. Botta and Sir Henry Layard, who discovered "Assyrian slabs," or bas-reliefs, but that was thirty-eight years ago; and as there have been no sculptured slabs discoverer in Babylonia, it is difficult to know what is to be understood by such an assertion. I do certainly agree with you that the matter ought not to be allowed to rest, but that the public should insist upon a thorough examination into the matter.

20. In conclusion, I must touch upon one more point, which appeared near the end of the criticism under discussion, about the duty of public servants to their superiors. You say, "With the terror of the decision in this case before them, all members of the public service will be in duty bound to consider whether they are able to afford the expenses of an action at law, and the enormous costs which follow in its train, before they report unpleasant truths to their superiors."

21. It will be indeed a sad day for an old public servant, who has spent the best part of bis life in the service of his adopted country, and held with undiminished confidence important appointments of trust under the Crown, to be debarred from obtaining justice elsewhere when it is denied him isy the department under which he served with honour, credit, and success for many a year, when his character is unjustifiably assailed.

6 Gloucester Walk, Kensington, W.

H. RASSAM.

[WE are much surprised that $\mathrm{Mr}$. Rassam has taken our article as personal to himself, as we dealt with the thefts in question only from a public point of view, and they might have happened, we suppose, if $\mathrm{Mr}$. Rassam had never existed.

We make the following comments on some of his paragraphs :-

Para. 4. We were not aware that Mr. Rassam had been appealing for a Court of Inquiry. There is no doubt that cause has been shown for a Treasury inquiry in the interests of the public and future explorers, and we hope it will be pressed for.

Para. 6. It was no part of our duty to sift the evidence. The point is that evidence was given (see Pall Mall Gazette, June 30). Did not the British Museum accountant go into ihe witness-box to state the amounts paid for tablets? and was not the evidence dispensed with because Dr. Budge's "vague" evidence was accepted as sufficient?

Paras. 7 and 8 . We referred to the evidence given in Court. What else could we do? It was not disproved in Court, or we should have said so.

Para. 9. This is a statement with which only the Trustees of the British Museum can deal. We, of course, are bound to accept Mr. Rassam's statement as he makes it.

Para. Io. We do not quite seize the point of Mr. Rassam's remark here. The statement as to the greater value of the tablets not received from him was made by the defendant; it is not ours.

Paras. I I and 12. We can only repeat that the public is interested in knowing that of 134,003 pieces of inscribed clay sent home from Babylonia-it really does not matter by whom, 125,000 have been termed rubbish by Sir H. Rawlinson one of the trustees, the principal librarian, and the present keeper of the collection. It was not necessary to refer to any suburdinate official, or to point out the singular fact that he gave evidence contrary to that of three of his official superiors.

Para. 13. We quite agree that it is most startling to hear that, in Sir Heny Rawlinson's opinion, so much of what Mr. Rassam sent home was rubbish. We presume that Mr. Rassam was startled when Sir Henry Rawlinson's deposition was read in Court; that is the reason, perhaps, that he forgot it, as he appears to have done.

Para. 15. Dr. Budge's reports could not be revealed by us because we do not possess them, and have never seen them. All the facts stated were given in evidence to which alone we professed to refer.

Pura. I7. Here we cordially agree with Mr. Rassam; as before stated, in our opinion a Treasury inquiry into the expenditure of the public funds on, and the method of carrying out, excavations in the region in question since, say, 1846 , is most desirable.

Paras. 18 ant 19 . The article was not written by an expert, and perhaps the word "bas-relief" would have been better than "slab." But there is no doubt about what we mean. Murray's "Handbook to Dorsetshire" informs us that at Canford Hall " a gallery connected with the house by a cloister is devoted to a series of Assyrian sculptures brought from
Nineveh." These sculptures-not to call them slabs-2re described as "winged lions and bulls, bas-reliefs, \&c, similar to those in the British Museum." Now, if there are many such galleries in England, and the objects were obtained at a low price, the whole question of excavation at the public expense is raised. -ED. NATURE.]

\section{Bishop's Ring.}

BISHOP's RING still continues very conspicuous about sunset more so than it was for a long time previous to last November, though not so much so as at the end of 1883 . It is evident there must have been an addition of some kind to the dust of our atmosphere last November, a considerable part of which yet remains. The light-coloured dust wisps re uppeared faintly after the date (April 1o) of my letter (p. 582), but have now entirely disappeared again (I have not seen them since July 20); the texture of the sky in the ring being perfectly smooth lately. I have not seen any other peculiar sunset phenomena of late, though Señor Arcimis (Director of the Meteorological Institute) tells me the sun=ets are very brilliant at Madrid. He says he is satisfied that Bishop's Ring did not exist in Spain before the Krakatoa eruption; and he agrees with me that it has never since entirely disappeared about sunset.

Sunderland, September I I.

T. W. Backhouse.

\section{Spring and Autumn of 1893 .}

As the peculiarities of this season are receiving attention in your pages, the following notes of things in this part of England may perhaps interest some of your readers.

On March 25 the following flowers were in bloom :-

Adoxa.

Golden Saxifrage.

Speedwel!

Wood Sorrel.

Snowdrop.

Crocus (nearly over).

Grape-hyacinth.

Wood anemone.

Primrose.

Violet (the white, nearly over).

Hazel (nearly over).

Larch.

Celandine.

Cuckoo fluwer.

Star-wort.

Broom.

Peach.

Gooseberry

Currant.

Willow (nearly over).

Cherry.

At the sxme date, the elm had been in fl swer for weeks;" the ash was in full bud; one or two sycamores in leaf; chestnuts in early leaf, and showing flower buds. The helibore had been out long ago; hyacinths were beginning to fower; a few pear buds had burst; the elms and hawthorns had shown green for several dayc. Butterfiles had been seen for several days.

The early heat did not, I suspect, suit all our spring flowers. I saw scarcely anything this year of two of our wall-plants which are usually abundant--he Drabix verna and the Saxifraga tridactylites.

On March 27 bluebells were found in flower.

The state of things now on September $\mathrm{I} 2$ is as curious.

The wild roses (both Rosa canina and arvensis) are again flowering in the hedges-in some cases in great profusion; there are now, or a few days ago have been, in blossom the following:
Apple.
Holly.
Buberis Darwini.
Kerria.
Wild strawberry.
Dog violets.
Rhododendron.

Some of the autumn flowers appear to me to have suffered from the heat and, perhaps, the drought. I have not seen the Spiranthes autumnalis, usually quite abundant here; and the Colchicum autumnale has been far less abundant than usual. Some garden bulbs have probably suffered in the same way.

I may add that wasps have been in extraordinary numbers; ant that we have found two or three of the nests of the treewasp similar to the one depicted in your papar on the 7 th inst.

Failand, near Bristol, September I2. EDIV. FRY.

\section{NOTES.}

Mr. W. Saville-Kent, at present engaged as Commissioner of Fisheries to the Government of Western Australia, has shipped to London a large collection of the 